Trakya Eğitim Dergisi

Cilt 9, Sayı 4

2019 Ek Sayı

Aralık 2019, 757-770

Geliş Tarihi: 12.02 .2019

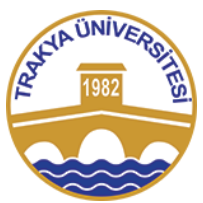

ISSN: 2630-6301
Trakya Journal of Education

Volume 9, Issue 4

2019 Additional Issue

December 2019, 757-770

Yayına Kabul Tarihi: 06.12.2019

DOI: $10.24315 /$ tred.526233

Araştırma Makalesi

\title{
The Impact of Educational Films on Attitude and Awareness towards Environmental Problems
}

\author{
Ĕ̆itsel Filmlerin Çevre Sorunlarına Yönelik Tutum ve Farkındalığa Etkisi
}

\section{Semra BENZER ${ }^{1}$, Ezgi GÜVEN YILDIRIM², Ayşe Nesibe ÖNDER ${ }^{3}$}

\begin{abstract}
Öz: Bu çalışma ile sınıf öğretmenliği anabilim dalında öğrenim görmekte olan ikinci sınıf öğretmen adaylarının çevre sorunlarına yönelik tutum ve farkındalıklarına eğitsel filmlerin etkisinin incelenmesi amaçlanmıştır. $\mathrm{Bu}$ araştırmada iki grup rastgele oluşturularak deney ve kontrol grubu olarak atanmıştır ve çalışma nicel araştırma desenlerinden ön test son test kontrol gruplu yarı deneysel desene göre yürütülmüştür. Verilerin toplandığı katılımcılar, araştırmacının araştırma problemlerine cevap bulacağına inandığ kişileri seçmesine olanak veren amaçlı örnekleme ile belirlenmiştir. Araştırmada veri toplama araçları olarak "Çevre Sorunlarına Yönelik Farkındalık Ölçeği” ve "Çevre Sorunlarına Yönelik Tutum Ölçeği" kullanılmıştır. Araştırma sonucunda deney grubunda yer alan öğretmen adaylarının çevre sorunlarına yönelik farkındalık son test puan ortalamalarının kontrol grubundan daha fazla olduğu sonucuna ulaşılmıştır. Çalışmadan elde edilen diğer bir sonuçta ise deney ve kontrol grubunda yer alan öğretmen adaylarının son test tutum puan ortalamaları arasında anlamlı bir fark bulunamamıştır.
\end{abstract}

Anahtar sözcükler: Çevre sorunları, eğitsel film, farkındalık, tutum.

\begin{abstract}
This study aimed to examine the effects of educational films on the second-grade elementary school teacher candidates' attitudes and awareness towards environmental problems. . In this study, two pre-existing groups were randomly assigned to experimental and control groups, so the study was designed according to the pre-test post-test control group quasi-experimental design. Participants from whom data were gathered were identified through purposive sampling. The awareness scale towards environmental problems and the attitude scale towards environmental problems were used as data collection tools in the study. According to the results there was a significant difference between the awareness scale mean post-test scores in favor of the experimental group. Also, the attitude scale mean post-test scores of the teacher candidates were compared and there was no difference between the attitudes mean scores of the teacher candidates.
\end{abstract}

Keywords: Environmental problem, educational film, awareness, attitude.

\section{UZUN ÖZET}

\section{Giriş}

Eğitsel filmler eğitim öğretim süreci içerisinde 50 y1ldan beri var olan öğrenme nesnelerinden birisidir (Depover, Giardina, \& Marton, 1998). Öğrenme nesnesi, etkili öğrenmeyi sağlamak için tekrar tekrar kullanılabilen her türlü dijital kaynağı kapsamaktadır (Wiley, 2002; Polsani, 2003). South ve Monson'a (2000) göre öğrenme nesnesi ise, öğretimin hedeflerini sağlamak için tasarlanan veya kullanılan dijital ortamlar olup kavram haritaları ve grafiklerden başlayıp video ve etkileşimli simülasyonlara kadar uzanan geniş bir yelpazeyi içermektedir. Cebeci' ye (2003) göre de bir süreci veya bir işlemi gösteren kısa bir animasyonlar veya video filmleri (bir bitkinin büyüme evreleri, toprak kirliliğinin oluşması süreci vb); bir metin parçaları, bir görüntü veya diyagram, etkileşimli bilgisayar simülasyonları birer öğrenme nesnesidir. Eğitsel filmler de belirli bir konu hakkında bilgi vermek amaciyla hazırlanan söz konusu öğrenme nesnelerinden birisidir (Michel, Roebers, \& Schneider, 2007). Eğitsel filmler öğretimde başarının sağlanması için gereklidir (Wenger, 1943). Yapılan çalışmalarla eğitsel filmlerin karmaşık konulara geçmeden önce “ön örgütleyici” olarak (Michel, Roebers, \& Schneider, 2007) ve öğrencilerde bilimsel kavramları anlamlandırmaya ve zihinsel yapılarının oluşmasına katkı saylayacak bir materyal olarak kullanılabileceği belirtilmektedir (Barnett, Wagner, Gatling, Anderson, Houle, \& Kafka, 2006). Örneğin, McCormick, (2007) okul ve öğretim içerikli eğitsel filmlerin öğretmen eğitiminde kullanılması ile

\footnotetext{
${ }^{1}$ Doç. Dr, Gazi Üniversitesi, Gazi Eğitim Fakütesi, Matematik ve Fen Bilimleri Eğitimi Bölümü, Ankara - Türkiye, sbenzer@gazi.edu.tr, ORCID:0000-0002-8548-8994

${ }^{2}$ Doç. Dr, Gazi Üniversitesi, Gazi Eğitim Fakütesi, Matematik ve Fen Bilimleri Eğitimi Bölümü, Ankara - Türkiye, ezgiguven@gazi.edu.tr, ORCID:0000-0002-8378-700X

${ }^{3}$ Doç. Dr, Gazi Üniversitesi, Gazi Eğitim Fakütesi, Matematik ve Fen Bilimleri Eğitimi Bölümü, Ankara - Türkiye, nkoklukaya@gazi.edu.tr, ORCID:0000-0001-7677-8861
} 
filmlerdeki öğretmen öğrenci ilişkilerinin bir örnek teşkil edeceği bu sebeple de öğrencilerde öğretmenlik mesleğine yönelik olumlu tutum geliştirmelerinde etkili olabileceğini belirtmektedir. Yine Mitchell ve Weber (1999) öğretmenlerle ilgili filmlerin öğretmen adayları, öğretmenler, akademisyenler için kendi mesleki kimliklerini açıklığa kavuşturmalarında faydalı olduğunu ifade etmiştir. Whiteman (2009) ise eğitim amaçlı belgesel filmlerin geniş kitlelere ulaşma yani kitle eğitimi amaciyla kullanılabileceğini belirtmiştir. Ancak Bruner (2008) eğitsel filmlerin, öğrencilere doğrudan deneyim sunan araçlar değil, deneyimi dolaylı olarak sunan ve öğrenme-öğretme sürecini zenginleştiren araçlar olduğunu belirterek, eğitsel filmlerin etkili kullanılmasına katkı sağlamıştır. Yine Barnett Wagner, Gatling, Anderson, Houle ve Kafka, (2006) çalışmalarında popüler bilim kurgu filmlerinin öğrencilerin bilimsel kavramları öğrenmesinde ve zihinsel yapılarının oluşmasında etkili olduğunu belirtmiştir. Bunun yanı sıra Demircioğlu (2007) üst düzey düşünme becerileri olan sentez, analiz ve değerlendirme becerilerinin de eğitsel filmler aracılığıyla öğrencilere kazandırılabildiğini belirtmektedir. Yine eğitsel filmlerin öğrencilerin öğretmen, öğretim programı ve günlük hayatta fen konularına ilişkin görüşlerinin belirlenmesinde de etkili bir araç olarak kullanılabildiği araştırmacılar tarafindan belirtilmektedir (Köklükaya, 2014; Güven, 2015; Güven Yıldırım, Köklükaya, \& Selvi, 2015). Söz konusu çalışmalar, eğitsel filmlerin eğitim öğretim ortamlarında yararlı bir öğretim materyali olduğunu göstermektedir. Bu kapsamda bu çalışma ile sınıf öğretmenliği anabilim dalında öğrenim görmekte olan ikinci sınıf öğretmen adaylarının çevre sorunlarına yönelik tutum ve farkındalıklarına eğitsel filmlerin etkisinin incelenmesi amaçlanmıştır. Bu amaç doğrultusunda çalışmanın alt problemleri şu şekilde belirlenmiştir.

1. Deney ve kontrol gruplarının çevre sorunlarına yönelik farkındalık ölçeği ön test puan ortalamaları arasında istatistiksel olarak anlamlı bir fark var mıdır?

2. Deney ve kontrol gruplarının çevre sorunlarına yönelik farkındalık ölçeği son test puan ortalamaları arasında istatistiksel olarak anlamlı bir fark var mıdır?

3. Deney ve kontrol gruplarının çevre sorunlarına yönelik tutum ölçeği ön test puan ortalamaları arasında istatistiksel olarak anlamlı bir fark var mıdır?

4. Deney ve kontrol gruplarının çevre sorunlarına yönelik tutum ölçeği son test puan ortalamaları arasında istatistiksel olarak anlamlı bir fark var mıdır?

\section{Yöntem}

$\mathrm{Bu}$ araştırma nicel araştırma desenlerinden ön test son test kontrol gruplu yarı deneysel desene göre yürütülmüştür (Cook \& Campbell 1979). Verilerin toplandığ1 katılımcılar, araştırmacının araştırma problemlerine cevap bulacağına inandığı kişileri seçmesine olanak veren amaçlı örnekleme ile belirlenmiştir (Patton, 2002; Cohen, Manion, \& Morrison, 2007). Çalışma grubunu 2016-2017 eğitim ve öğretim yılının bahar döneminde Ankara ilindeki bir devlet üniversitesinde Sınıf Eğitimi Anabilim Dalı'nda öğrenim görmekte olan ve "Çevre Eğitimi" dersini alan 56 ikinci sınıf öğretmen adayı oluşturmaktadır. Araştırmada veri toplama araçları olarak "Çevre Sorunlarına Yönelik Farkındalık Ölçeği" ve "Çevre Sorunlarına Yönelik Tutum Ölçeği” kullanılmıştır. Çalışma 2016-2017 eğitim-öğretim yılı bahar döneminde, çevre eğitimi dersinde sınıf eğitimi anabilim dalında öğrenim görmekte olan ikinci sınıf öğretmen adayları ile yürütülmüştür. Uygulama sürecine başlamadan önce 2. Sınıf B ve C şubeleri yansız olarak deney $(\mathrm{N}=26)$ ve kontrol $(\mathrm{N}=30)$ grubu olarak atanmıştır. Her iki grupta da öğretmen adaylarına çevre sorunlarına yönelik farkındalık ölçeği ve çevre sorunlarına yönelik tutum ölçeği ön test olarak uygulanmıştır. Daha sonra deney grubuna eğitsel filmlerle işlenecek olan ders hakkında bilgilendirme yapılmıştır. Çevre eğitimi dersinin çevre sorunları ile ilgili olan dört haftalık sürecinde deney grubunda eğitsel filmlerle desteklenmiş şekilde ders işlenmiş, kontrol grubunda ise eğitsel filmler kullanılmamıştır. Deney grubunda her hafta dersin başında ortasında veya sonunda konu ile ilgili olarak 5-10 dakikalık eğitsel film izletilerek ders işlenmiştir. Veriler, uygulama süreci başlamadan önce ön test ve uygulama bitiminde son test olarak toplanmıştır. Araştırmadan elde edilen nicel verileri analiz etmek için SPSS 21 istatistik analiz programı kullanılmıştır. Öğrencilerin çalışmada kullanılan teste verdikleri yanıtların genel dağılımlarının belirlenmesi ve nicel verilerin normal dağılım gösterip göstermediğinin araştırılmasında betimsel istatistik tekniklerinden (mod, medyan, aritmetik ortalama, standart sapma değerleri) yararlanılmıştır. Test puanlarına ait merkezi eğilim (ortalama, mod ve medyan) ve merkezi dağılım (standart sapma, varyans, çarpıklık ve basıklık) değerleri rapor edilmiştir. Deney ve kontrol gruplarında yer alan öğrencilerin ön ve son test puan ortalamaları arasında anlamlı düzeyde bir fark olup olmadığını tespit etmek için bağımsız gruplar t-testi kullanılmıştır. Araştırmada yapılan bütün analizlerde anlamlılık düzeyi .05 olarak kabul edilmiştir. 


\section{Sonuç ve Tartışma}

Çevre sorunları konusun öğretiminde kullanılan eğitsel filmlerin çevre sorunlarına yönelik farkındalık ve tutum üzerine etkisinin incelendiği bu araştırmada ölçekler vasıtasıyla nicel veriler toplanmıştır. Araştırmaya katılan öğretmen adaylarının, çevre sorunlarına yönelik farkındalık ve tutum ölçeklerinin yanıtları, istatiksel yöntemle değerlendirilmiş ve elde edilen bulgulara göre aşağıda yer alan sonuçlara ulaşılmıştır.

Araştırmada öncelikle grupların farkındalık ölçeği ön test puan ortalamaları arasında anlamlı bir farklılık olup olmadığı araştırılmıştır. Eğitsel filmler ile çevre eğitimi verilen deney grubu öğretmen adayları ve eğitsel filmler kullanılmadan çevre eğitimi verilen kontrol grubu öğretmen adaylarının farkındalık ölçeği ön test puan ortalamaları arasında anlamlı düzeyde bir farklılık görülmemiştir $(\mathrm{p}>.05, \mathrm{t}=$ -,48). Çalışmada daha sonra deney ve kontrol grubunda yer alan öğretmen adaylarının farkındalık ölçeği son test puan ortalamaları karşılaştırılmış ve farkındalık ölçeği son test puan ortalamaları arasında deney grubu lehine anlamlı bir farkl11ık bulunmuştur $(\mathrm{p}<.05, \mathrm{t}=-4,64)$. Bu durumun nedeninin eğitsel filmlerin öğretim sürecine olan olumlu etkilerinden kaynaklandığı düşünülmektedir. Araştırmanın bir diğer bulgusu çevre sorunları konusun öğretiminde kullanılan eğitsel filmlerin öğretmen adaylarının çevre sorunlarına yönelik tutumlarına etkisi üzerinedir. Çalışmanın sonucunda yapılan analizler neticesinde, deney ve kontrol guruplarında yer alan öğretmen adaylarının uygulama öncesi tutum ölçeği puan ortalamaları arasında anlamlı bir farklılık bulunmamıştır $(\mathrm{p}>.05, \mathrm{t}=, 80)$. Uygulama sonrasında öğretmen adaylarının tutum ölçeği son test puan ortalamaları karşılaştırılmış ve ön test skorları ile benzer şekilde öğretmen adaylarının tutum puan ortalamaları arasında da bir farklılığa rastlanmamıştır $(\mathrm{p}>.05, \mathrm{t}=, 73)$. Sonuç olarak bu araştırmada öğretmen adaylarının çevre sorunlarına yönelik tutumlarında eğitsel film kullanımına bağlı olarak bir değişim olmamıştır. Bu durumunun nedeninin özellikle ilk yetişkinlik olarak bilinen bu yaş grubunda tutumların değişime direnç göstermesi olduğu düşünülmektedir.

Araştırma sonucunda ortaya çıkan bulgulardan hareketle, eğitsel filmlerle işlenen çevre eğitimi derslerinin çevre sorunlarına yönelik farkındalık üzerine olumlu yönde etkisi olduğu sonucuna varılmıştır. Çalışmada kullanılan eğitsel filmler ise tutumlar üzerine olumlu bir etki yaratmamıştır. Bu kapsamda çalışmanın sonuçları göz önünde bulundurulduğunda, bu konuyla ilgili yapılacak diğer araştırmalarda farklı örneklem gruplarının çalışmaya dahil edilmesi önerilmektedir. Böylelikle eğitsel filmlerin çevre sorunlarına yönelik farkındalık ve tutumlar üzerine olan sonuçlarının daha yaygın hale geleceği düşünülmektedir. Yine başka araştırmalar ile çevre eğitiminde kullanılan eğitsel filmlerin farklı değişkenler üzerine olan etkisinin araştırılması mümkündür. Özellikle ilk ve ortöğretim öğrencilerine ve ileride bu öğrencilere öğretmen olacak öğretmen adaylarına yönelik çevre eğitimi etkinlikleri planlanırken birçok duyu organını birden uyaran, öğrencilerin dikkatini çekip onları çevreye yönelten, çevreye yönelik etkinliklere ve çevre sorunlarını çözmeye motive eden öğrenci merkezli alternatif öğretim yöntem ve teknikleri kullanılmasının önemli olduğu düşünülmektedir.

\section{INTRODUCTION}

In today's world, environmental problems have begun to widely show themselves with the development of science and technology and the increasing needs of human beings with a rapidly increasing population. Considering the past, it is known that the first destruction in the nature came into being with the invention of fire. Then, industrialization, urbanization and similar developments have gradually brought environmental problems up to the present day. Today, environmental education is the most important tool for the elimination of environmental problems, which may otherwise lead to the end of the world (Erten, 2006). Some of the key objectives of environmental education are to raise individuals' awareness of environmental problems, motivate individuals in this way, and develop solutions to address both local and global problems and to prevent them (UNESCO-UNEP, 1976; UNESCO-UNEP, 1978; North American Association for Environmental Education, 2004). Achieving these goals can only be possible by creating individuals' awareness of environmental protection by developing responsible behaviors, through education on environmental issues (Sauvé, 2005; Cole, 2007; Toumey, Besley, Blanchard, Brown, Cobb, Ecklund, Glass, Guterbock, Kelly, \& Lewenstein, 2010). Environmental education is a continuous learning process that enables individuals to get to know concepts related to their environment, enables them to develop a positive attitude toward the environment and a high level of awareness of and sensitivity to environmental problems, and also to acquire knowledge, skills, attitudes and values for solving environmental problems to leave a healthy, clean and livable environment for future generations (Vaughan, Gack, Solorazano, \& Ray, 2003). Two of the major outputs of environmental education are to create in 
individual's positive attitudes towards and a high level of awareness of solving and preventing environmental problems. However, studies show that both individuals' awareness of environmental problems (Shobeiri, Omidvar, \& Prahallada, 2007; Baptiste, 2008; Hassan, Juahir, \& Jamaludin, 2009; Ahuja, 2010; Hassan, Noordin, \& Sulaiman, 2010; Larijani, 2010; Aminrad, Zakaria, \& Hadi, 2011; Kaushal \& Singhal, 2011) and attitudes towards environmental problems (Altın, 2001; Özmen, Çakmakç1 Çetinkaya, \& Nehir, 2005; Atasoy \& Ertürk, 2008) are low. Ensuring that environmental education is learned and that awareness of and attitudes towards environmental problems are developed is very closely related to teachers as well as the methods and techniques that are used (Kostova \& Atasoy, 2008). For this reason, the education and training process needs to be supported by experience gained in various projects (Karahan \& Roehrig, 2015), training courses (Chawla \& Cushing, 2007) and extracurricular learning environments (Farmer, Knapp, \& Benton, 2004; Tal, 2004; Kossack \& Bogner, 2012). Environmental education should be handled with different techniques in order to provide an environmental education in which the environment, creatures, and natural life can be endeared easily without bothering the individuals, as mentioned in the studies in question (Gülay \& Önder, 2011). When the literature is examined, it is seen that there are studies in environmental education in which analogies (Aubusson, Harrison, \& Ritchie, 2006; Vishwanath, 2006), projects (Güven, 2011; McGibbon \& Van Belle, 2015), problem-based learning (Dalhgren \& Öberg 2001), educational games (Zualkernan, Jibreel, Tayem, \& Zakaria, 2009) and the predict, observe, explain method (Köseoğlu, Tümay, \& Kavak, 2002; Russell, Lusac, \& Mcrobbie, 2003, 2004; Chew, 2008; Bilen, 2009; Özyılmaz Akamca \& Hamurcu, 2009) have been used. One of the techniques that can be used in environmental education is the use of educational films.

Educational films are one of the learning objects that have existed for 50 years in the educational process (Depover, Giardina, \& Marton, 1998). A learning object includes all kinds of digital resources that can be used repeatedly to ensure effective learning (Wiley, 2002; Polsani, 2003). According to South and Monson (2000), a learning object is a digital environment designed or used to achieve the goals of instruction, and includes a wide range of topics, from concept maps and graphics to video and interactive simulations. According to Cebeci (2003), a short animation or video film, a piece of text, an image or a diagram and an interactive computer simulation are all learning objects that show a process or an operation (growth stages of a plant, the process of soil pollution, etc.). Educational films are also one of learning objects in order to give information about a specific subject (Michel, Roebers, \& Schneider, 2007). Educational films are necessary for achieving success in teaching (Wenger, 1943). Studies have shown that educational films can be used as "advance organizers" (Michel, Roebers, \& Schneider, 2007) and as a material to contribute to the understanding of scientific concepts and the formation of mental structures in students before moving on to complex subjects (Barnett, Wagner, Gatling, Anderson, Houle, \& Kafka, 2006). For example, McCormick (2007) has stated that the use of educational films with school- and instruction-related content in teacher education can be effective in promoting positive attitudes toward the teaching profession in students, as teacher-student relationships in films may serve as an example. Mitchell and Weber (1999) has also stated that films about teachers are useful for prospective teachers, teachers, and academics to be able to clarify their professional identities. Whiteman (2009) stated that educational documentary films could be used for reaching large masses, that is, for education of masses. However, Bruner (2008) has contributed to the effective use of educational films, noting that educational films are tools that provide experiences to students not directly but indirectly, as well as enriching the learningteaching process. Again, Barnett Wagner, Gatling, Anderson, Houle and Kafka (2006) stated that popular science fiction movies were effective in students' learning of scientific concepts and their formation of mental structures in their study. In addition to this, Demircioğlu (2007) has stated that students can be upskilled with the skills of synthesis, analysis and evaluation, which are higher-order thinking skills, through educational films. It has also been pointed out by researchers that educational films can be used as an effective tool in determining student views on teachers, curriculum and science in everyday life (Köklükaya, 2014; Güven, 2015; Güven Yıldırım, Köklükaya, \& Selvi, 2015). These studies show that educational films are useful teaching materials in teaching and learning environments. In this context, this study aimed to examine the effects of educational films on the second-grade elementary school teacher candidates' attitudes and awareness towards environmental problems. Based on this aim, the sub-problems of the study were determined as follows.

1. Is there a statistically significant difference between the experimental and control groups in terms of mean pre-test scores of the awareness scale towards environmental problems?

2. Is there a statistically significant difference between the experimental and control groups in terms of mean post-test scores of the awareness scale towards environmental problems? 
3. Is there a statistically significant difference between the experimental and control groups in terms of mean pre-test scores of the attitude scale towards environmental problems?

4. Is there a statistically significant difference between the experimental and control groups in terms of mean post-test scores of the attitude scale towards environmental problems?

\section{METHOD}

This study was conducted according to the pre-test post-test control group quasi-experimental design (Cook \& Campbell, 1979). The quasi-experimental design is a model, the scientific value of which comes after true experimental designs, and in which the controls required by true experimental designs cannot be fully ensured (Karasar, 2004). The random selection of a sample and the random assignment of sampled members to experimental and control groups are distinctive and mandatory features of the experimental design. No true experimental research can be carried out if random assignment is not possible. In such cases, researchers use quasi-experimental investigations that involve all the features of experimental investigations, except for random assignment of participants (Mertler \& Charles, 2011). In this study, two pre-existing groups were randomly assigned to experimental and control groups, so the study was designed according to the pre-test post-test control group quasi-experimental design.

\section{Participants}

Participants from whom data were gathered were identified through purposive sampling, which allows the researcher to select people through whom he believes he would find answers to the research problems (Patton, 2002; Cohen, Manion, \& Morrison, 2007). The sample consisted of 56 second-grade prospective teachers who were studying in the Department of Elementary Education at a state university in Ankara and enrolled in the environmental education course during the spring semester of the 2016-2017 academic year.

\section{Data Collection Tools}

The awareness scale towards environmental problems and the attitude scale towards environmental problems were used as data collection tools in the study.

\section{Awareness Scale towards Environmental Problems}

The scale was developed by Güven and Aydoğdu (2012) and consisted of a total of 44 items. The scale was prepared with the likert type of "yes," "no" and "no idea." The score that could be taken from the scale varied between 44 and 132. An increase in the total score from the scale indicated an increase in the awareness level of a person about environmental problems. The Cronbach Alpha reliability coefficient of the scale was given as 0.90 .

\section{Attitude Scale towards Environmental Problems}

The scale was developed by Güven (2013) and consisted of a total of 45 items. The scale was prepared with the likert type of "yes," "no" and "no idea." The score that could be taken from the scale varied between 45 and 135. An increase in the total score from the scale indicated an increase in the attitude level of a person towards environmental problems. The Cronbach Alpha reliability coefficient of the scale was given as 0.88 .

\section{Research Process}

The study was carried out during the spring term of 2016-2017 academic year, on second-grade teacher candidates who were studying in the Elementary Education Department and enrolled in the Environmental Education course. Before starting the research process, the groups B and C of the second grade were randomly assigned as the experimental $(\mathrm{N}=26)$ and control $(\mathrm{N}=30)$ groups, respectively. In both groups, the awareness scale towards environmental problems and the attitude scale towards environmental problems were applied as pre-tests to the teacher candidates. Next, the experimental group was informed that the course would be taught using educational films. During the 4 weeks of the Environmental Education course related to environmental problems, the course was taught with the aid of educational films in the experimental group, whereas educational films were not used in the control group. In the experimental 
group, each lesson was taught by having students watch a 5-to-10-minute instructional film about the subject at the beginning, midway through, or at the end of a lesson each week.

\section{Analysis of Data}

The data were collected as a pre-test before the research process started and as a post-test at the end of the research process. SPSS 21 statistical analysis program was used to analyze the quantitative data obtained from the study. Descriptive statistical techniques (mod, median, arithmetic mean, and standard deviation values) were used to determine the general distribution of responses-given by the students to the test used in the study-and to investigate whether the quantitative data had a normal distribution. The central tendency (mean, mode and median) and the central distribution (standard deviation, variance, skewness and kurtosis) of the test scores were reported. Independent samples t-test was used to determine whether there was a significant difference between mean pre and post-test scores of the students in the experimental and control groups. The significance level was accepted as .05 in all analyzes carried out in this study.

\section{FINDINGS}

The data of the study were obtained from the awareness and attitude scales applied to a total of 56 teacher candidates, 26 in the experimental group and 30 in the control group, before and after the research process. The quantitative findings and interpretations obtained from the analysis of these data on the research problems and sub problems are given below.

\section{Findings on Sub-Problems 1 and 2}

Before moving on to the findings of the research sub-problems 1 and 2, first it was determined what statistical method would be applied to the quantitative data obtained from the awareness scale used in the study. In quantitative research, in order to use parametric analysis methods, it is necessary that quantitative data obtained from all tests and scales during the study have normal distribution (Sim \& Wright, 2002; Çepni, 2007). For this reason, some analyses were performed to determine the statistical method to be applied to the data obtained from the awareness scale, the findings obtained from the analyses were transferred to tables, and whether the scores were normally distributed was examined (Table 1).

Table 1. The descriptive data of the groups' pre-test and post-test mean scores of the awareness

\begin{tabular}{llcccccccc}
\hline Scale & Group & $\mathrm{N}$ & $\mathrm{M}$ & $\mathrm{SD}$ & Med. & Mod & Kurt. & Skew. & Var. \\
\hline Awareness & Experimental & 26 & 113.88 & 3.66 & 113 & 112 & .60 & .17 & 13.39 \\
Pre-test & Control & 30 & 113.27 & 5.56 & 112.5 & 112 & .38 & -.38 & 30.96 \\
Awareness & Experimental & 26 & 119.19 & 3.14 & 119.5 & 119 & .23 & -.62 & 9.84 \\
Post-test & Control & 30 & 114.87 & 3.74 & 115 & 114 & .36 & -.69 & 13.98 \\
\hline
\end{tabular}

The descriptive data on the mean pre-test and post-test scores of the awareness scale are shown in Table 1. According to the data in the table, the mean pre-test score of the teacher candidates in the experimental group $(M=113.88)$ was close to the mean post-test score $(M=113.27)$ of the teacher candidates in the control group. The awareness scale mean pre-test scores were high for both groups. With regard to the awareness scale mean post-test scores of the groups, the awareness scale mean post-test score of the teacher candidates in the experimental group $(\mathrm{M}=119.19)$ was found to be higher than the awareness scale mean post-test score of the teacher candidates in the control group $(\mathrm{M}=114.87)$. Considering the data in the table, it was seen that there was an increase in the mean awareness scores of the teacher candidates in both groups from the pre-measurements made before the research process and the post-measurements made after the research process. But, this increase was more in the experimental group.

With regard to Table 1, mean, mode and median values of the pre-test awareness scale scores of the experimental group and those of the control group were close to each other, respectively. As can be seen from the table, regarding the awareness scale, the mean, mode and median post-test scores of the experimental group were almost equal to the mean, mode and median post-test scores of the control group, respectively. The fact that the mean, mode, and median values for the data from all tests were close to each other is interpreted as that the data were normally distributed (Köklü, Büyüköztürk, \& Bökeoğlu, 2006). When the kurtosis and skewness values in Table 1 are examined, it is seen that these values were also suitable for normal distribution. The skewness values were between -2 and +2 , showing that the data obtained from the awareness scale were normally distributed (George \& Mallery, 2003). 
Parametric tests were used in the analysis of the data, which were found to show normal distribution based on the descriptive statistics. Starting from this, it was aimed to determine whether there was a significant difference between the awareness scale mean pre-test scores of the teacher candidates in the experimental and control groups before the research process. Thus, an independent samples t-test was done using the awareness scale pre-test scores of the groups (Table 2).

Table 2. The results of independent samples t-test on pre-test awareness scores of the groups

\begin{tabular}{lccccc}
\hline Group & $\mathrm{N}$ & $\mathrm{M}$ & $\mathrm{SD}$ & $\mathrm{t}$ & $\mathrm{p}$ \\
\hline Experimental & 26 & 113.88 & 3.66 & \multirow{2}{*}{-.48} & \multirow{2}{*}{.63} \\
Control & 30 & 113.27 & 5.56 & & \\
\hline
\end{tabular}

Considering the data in the table, there was no significant difference between the awareness scale mean pre-test scores of the teacher candidates in the experimental and control groups $(\mathrm{M}=113.88$ in the experimental group, $\mathrm{M}=113.27$ in the control group) before the research process ( $\mathrm{p}>.05, \mathrm{t}=-.48$ ). The fact that there was no significant difference between the awareness scale mean pre-test scores of the teacher candidates before the research process began was appropriate for the purpose of determining the effectiveness of the educational films used in the research process.

Independent groups' t-test results on whether there was any difference after the research process between the mean awareness scale scores of the teacher candidates in the experimental group and the control group are given in the table below (Table 3).

Table 3. The results of independent samples t-test on post-test awareness scores of the groups

\begin{tabular}{lccccc}
\hline Group & $\mathrm{N}$ & $\mathrm{M}$ & $\mathrm{SD}$ & $\mathrm{t}$ & $\mathrm{p}$ \\
\hline Experimental & 26 & 119.19 & 3.14 & \multirow{2}{*}{-4.64} & \multirow{2}{*}{00} \\
Control & 30 & 114.87 & 3.74 & & \\
\hline
\end{tabular}

Considering the data in Table 3, the awareness scale mean post-test score of the teacher candidates in the experimental group was found to be $M=119.19$, while the awareness scale mean post-test score of the teacher candidates in the control group was found to be $M=114.87$. There was a significant difference between the awareness scale mean post-test scores of the teacher candidates in the experimental and control groups after the study $(\mathrm{p}<.05, \mathrm{t}=-4.64)$.

\section{Findings on Sub-Problems 3 and 4}

Before moving on to the findings of the research sub-problems 3 and 4, some analyzes were made to determine the statistical method to be applied to the data obtained from the attitude scale, the findings obtained from the analyzes were transferred to tables, and whether the scores were normally distributed was examined (Table 4).

Table 4. The descriptive data of the groups' pre-test and post-test mean scores of the attitude scale

\begin{tabular}{clcccccccc}
\hline Scale & Group & $\mathrm{N}$ & $\mathrm{M}$ & $\mathrm{SD}$ & Med. & Mod & Kurt. & Skew. & Var. \\
\hline Attitude & Experimental & 26 & 116.15 & 6.66 & 117 & 117 & .62 & -.01 & 44.36 \\
Pre-test & Control & 30 & 117.57 & 6.53 & 118 & 117 & .22 & -.06 & 42.67 \\
Attitude & Experimental & 26 & 118.77 & 8.72 & 120 & 120 & -.36 & -.41 & 76.11 \\
Post-test & Control & 30 & 119.47 & 6.30 & 119 & 117 & 1.54 & -.21 & 39.64 \\
\hline
\end{tabular}

Considering Table 4, it is seen that at the pre-test, the mean attitude score of the teacher candidates in the experimental group ( $\mathrm{M}=116.15)$ was close to the mean attitude score of the teacher candidates in the control group ( $\mathrm{M}=117.57)$. When the mean post-test scores of the groups were examined, it was also noteworthy that the attitude post-test mean score of the experimental group $(\mathrm{M}=118.77)$ and the attitude post-test mean score of the control group $(\mathrm{M}=119.47)$ were close to each other. It was seen that the premeasurements made before the research process and the post-measurements made after the research process showed an increase in the mean attitude scores of the teacher candidates in both groups. However, there was no significant difference between groups in the post-tests. Again, according to Table 4, the pre-test mean scores and mode and median values of the teacher candidates in the experimental and control groups 
were very close to each other. Similarly, mean, mode and median values of the post-test scores of the experimental group and those of the control group had values close to each other, respectively. The fact that the mean, median, and mode values were similar to each other, and the kurtosis and skewness values of the data indicate that the data were normally distributed (George \& Mallery, 2003, Köklü, et al., 2006).

The use of parametric tests decided in the analysis of the data, which were found to show normal distribution based on the descriptive statistics. An independent t-test was run to determine whether there was a significant difference between the attitudes mean pre-test scores of the groups.

Table 5. The results of independent samples t-test on pre-test attitude scores of the groups

\begin{tabular}{lccccc}
\hline Group & $\mathrm{N}$ & $\mathrm{M}$ & $\mathrm{SD}$ & $\mathrm{t}$ & $\mathrm{p}$ \\
\hline Experimental & 26 & 116.15 & 6.66 & \multirow{2}{*}{80} & \multirow{2}{*}{43} \\
Control & 30 & 117.57 & 6.53 & & \\
\hline
\end{tabular}

According to the data in Table 5, the attitude scale mean pre-test score was $M=116.15$ for the teacher candidates in the experimental group and $\mathrm{M}=117.57$ for the teacher candidates in the control group. There was no significant difference between the attitude scale mean pre-test scores of the teacher candidates in the experimental and control groups $(\mathrm{p}>.05, \mathrm{t}=.80)$.

No significant difference was found between the attitude scale mean pre-test scores of the teacher candidates in the experimental and control groups. An independent samples t-test was applied to post-test scores of the experimental and control groups (Table 6).

Table 6. The results of independent samples t-test on post-test attitude scores of the groups

\begin{tabular}{lccccc}
\hline Group & $\mathrm{N}$ & $\mathrm{M}$ & $\mathrm{SD}$ & $\mathrm{t}$ & $\mathrm{p}$ \\
\hline Experimental & 26 & 118.77 & 8.72 & \multirow{2}{*}{35} & .73 \\
Control & 30 & 119.47 & 6.30 & & \\
\hline
\end{tabular}

Considering the data in the table, the attitude scale mean post-test score of the teacher candidates in the experimental group was found to be $\mathrm{M}=118.77$, while the attitude scale mean post-test score of the teacher candidates in the control group was found to be $M=119.47$. There was no significant difference between the attitude scale mean post-test scores of the groups after the research process $(p>.05, t=.35)$.

\section{RESULTS AND DISCUSSION}

In this study, educational films used in teaching environmental issues were examined in terms of their effects on awareness and attitudes towards environmental problems. Quantitative data were collected by means of scales. The responses of the teacher candidates participating in the study on the environmental awareness and attitude scales were statistically evaluated, and the following results were obtained according to the findings.

In the study, first, it was investigated whether there was a significant difference between the awareness scale mean pre-test scores of the groups. There was no significant difference between the awareness scale mean pre-test scores of the teacher candidates in the experimental group who were given environmental education through educational films and those in the control group who were given environmental education without using educational films ( $\mathrm{p}>.05, \mathrm{t}=-.48)$. Next, the awareness scale mean post-test scores of the teacher candidates in the experimental and control groups were compared in the study. There was a significant difference between the awareness scale mean post-test scores in favor of the experimental group $(\mathrm{p}<.05, \mathrm{t}=-4.64)$. It is thought that this is caused by the positive effects of educational films on the teaching process. When the literature is examined, there are many studies emphasizing the positive effects of the use of educational films in the learning and teaching process. Educational films used in the learning environment provide easier understanding of difficult-to-understand topics; they facilitate the learning of a subject by being able to be rewound and fast forwarded, or to be paused when desired, based on their feature that enables reviewing the subject; they are positively influential in memorability; and they embody abstract concepts and provide learners with positive learning experiences (İnce Yakar, 2013). Watts (2007), for example, has stated that films are motivating students to learn by offering a rich learning experience. According to Birkök (2008), the use of educational films in the teaching process makes it easier to understand complex information; all the fictionalized information is transferred dynamically, visually and audibly; and behavioral models can be transferred to students as well as the instruction. Stoddard (2009) has also stated that films are an effective tool for the learning and teaching process and 
that films are an unbiased source of knowledge. Moreover, in the study of Akbaş, Canoğlu and Ceylan (2015), educational short films were found useful by teacher candidates who watched them. In the results obtained from this study, teacher candidates often talked about positive contributions of educational short films such as facilitating the teaching process, ensuring interest and establishment of relationships with everyday life, improving imagination, providing persistence, providing opportunities for different types of intelligence, ensuring learning by having fun, and ensuring acquisition of the ability to question. Nevertheless, while educational films provide many benefits in the learning environment, it is noteworthy that there is a very limited number of studies using educational films in environmental education. Much less of these studies are about awareness of the environment. For example, Selanik Ay (2010) has stated that educational films help students learn about environmental issues, recognize environmental problems, gain knowledge of environmental problems, and build environmental awareness. Moreover, Barbas, Paraskevopaulos and Stamou (2007) examined the effects of environment-related films on students' perceptions of the environment. As a result of the study, it was concluded that the films related to the natural environment had positive effects on the awareness of and sensitivity to the environment. Alim (2006) also emphasized the role of audiovisual media on environmental education in his study. Another study carried out by Takmaz, Y1lmaz and Kalpaklı (2018) aimed to examine how Avatar, a science-fiction movie, as a teaching material influenced one to think about nature and environmental education. As a result of the study, it was seen that the Avatar movie tried to raise awareness of nature/environment education and made extensive emphasis on behavior towards the environment. Therefore, due to the positive effects of the movie in question, it was concluded that it could make important contributions as an effective teaching material. Again, Demirkuş, Bozkurt and Gülen (2017) prepared virtual materials, in their study, to help students conceptualize popular environmental concepts and conceptual clusters and to help them learn the concepts properly. In the material prepared by the researchers, 712 concept film DVDs related to popular environmental concepts were prepared from 90 scientific films broadcasted in documentary channels.

Another finding of the study was the effect of educational films used in the teaching of environmental issues on the attitudes of prospective teachers towards environmental problems. As a result of the analyses, there was no significant difference between the attitude scale mean pre-test scores of the teacher candidates in the experimental and control groups before the research process $(\mathrm{p}>.05, \mathrm{t}=.80)$. After the research process, the attitude scale mean post-test scores of the teacher candidates were compared. Similar to the pre-test scores, there was no difference between the attitude mean scores of the teacher candidates, either $(\mathrm{p}>.05, \mathrm{t}=.35)$. As a result, there was no change in the attitudes of teacher candidates towards environmental problems in this study depending on the use of educational films. It is thought that the reason for this is resistance to change in attitudes, especially in this age group, which is known as the first adulthood. This period between the ages of 12 and 30, in which attitudes are shaped and crystallized, is called the critical period, and the attitudes acquired in this period do not change easily (Sears \& Abeles, 1969; Morgan, 2000). However, when the literature is examined, there are some studies showing that, unlike the results of this study, educational films have positive effects on attitudes. For example, McCormick (2007) emphasized that the use of movie films with instructional content in teacher education would increase the attitudes of teacher candidates. Based on the study of Akridge and Balkanski (1990), it has been determined that with the use of educational films in the learning environment, students have a pleasant time in the process and that their attitudes and motivation towards lessons increase. Kaşkaya, Ünlü, Akar and Özturan Sağırlı (2011) have showed, in their study, that movie films with educational content have a significant and positive difference in students' attitudes towards profession and self-efficacy perceptions. Moreover, there are similar studies in the literature that emphasize the positive effects of educational films on attitudes (Ekem, 1990; Cavanaugh \& Cavanaugh, 1996, 2004; Çemrek, et al., 2005; Birkök, 2008; Laprice \& Winrich, 2010; Sürmeli, 2012). It also draws attention that there are many studies in the literature emphasizing the effectiveness of learner-centered and active teaching methods in the development of individuals' attitudes towards the environment and environmental problems (Palmberg \& Kuru, 2000; Ballantyne \& Packer, 2002; Oweini \& Houri, 2006; Schusler \& Krasny, 2008; Benzer, 2010; Tahiroğlu, Yıldırım, \& Çetin, 2010; Borhan \& İsmail, 2011).

As a result of the research findings, it was concluded that environmental education courses taught using educational films had a positive effect on students' awareness of environmental problems. The educational films used in this study, on the other hand, did not have a positive effect on attitudes. In this context, considering the results of the study, it is recommended that different groups of samples be included in research studies to be carried out on this subject. It is thought that the results of educational films about "awareness of" and "attitudes towards" environmental problems will, thus, become more widespread. With further research, it is possible to investigate the effect of educational films used in environmental education 
on different variables. It is thought to be important to use student-centered alternative teaching methods and techniques that motivate many sensory organs, attract students, draw their attention to the environment, and motivate them to participate in environmental activities and to solve environmental problems, while planning environmental educational activities for elementary and secondary school students and for future teacher candidates who will be teachers of these students. 


\section{REFERENCES}

Ahuja, L. R. (2010). A study of environmental awareness among B.Ed. teacher trainess of govt. Aided and selffinanced colleges. International Research Journal, 2(11- 12), 28-30.

Akbaş, O., Canoğlu, S. N. \& Ceylan, M. (2015). Eğitsel kısa film ve videoları yeniden düşünmek: Eğitsel kısa film ve video yarışmasına ilişsin bir değerlendirme. [Re-thinking educational short films and videos: An evaluation of educational short films and video competitions]. Kuramsal Eğitim Bilim Dergisi, 8(2), 282-296.

Akridge, J. R. \& Balkanski, M. (1990). Technology and physics of thin film insertion compounds. (Ed: Julien, C. \& Balkanski, M.). Solid state microbatteries. New York: Plenum Press.

Alım, M. (2006). Avrupa Birliği üyelik sürecinde Türkiye'de çevre ve ilköğretimde çevre eğitimi.[ Environment and environmental education in primary school in Turkey within the process of the membership of European Union]. Kastamonu Eğitim Fakültesi Dergisi, 14(2), 599-616.

Altın, M. (2001). Biyoloji ögretmeni adaylarında çevre eğitimi [Environmental education at pre-service biology teachers]. Yüksek Lisans Tezi. Gazi Üniversitesi Eğitim Bilimleri Enstitüsü, Ankara.

Aminrad, Z., Zakaria, S. Z. \& Hadi, A. S. (2011). Influence of age and level of education on environmental awareness and attitude: case study on Iranian students in Malaysian universities. Medwell Journals, 6(1), 15-19.

Atasoy, E. \& Ertürk, H. (2008). İlköğretim öğrencilerinin çevresel tutum ve çevre bilgisi üzerine bir alan araştırması [A field study about environmental knowledge and attitudes of elementary school students]. Erzincan Eğitim Fakültesi Dergisi, 10(1), 105-122.

Aubusson, P. J., Harrison, A. G. \& Ritchie, S. M. (2006). Metaphor and analogy in science education. Dordrecht, The Netherlands: Springer.

Ballantyne, R. R. \& Packer, J. (2002). Nature-based excursions: school students' perceptions of learning in natural environments. International Research in Geographical and Environmental Education, 11(3), 218-231.

Baptiste, A. K. (2008). Evaluating environmental awareness: a case study of the Nariva Swamp, Trinidad. Unpublished Ph.D Thesis. State University of New York College of Environmental Science and Forestry.

Barbas, A. T., Paraskevopaulos, S. \& Stamou, G. A. (2007). The effect of nature documentaries on students' environmental sensitivity a case study. Learning Media and Technology, 3(1), 61-69.

Barnett, M., Wagner, H., Gatling, A., Anderson, J., Houle, M. \& Kafka A. (2006). The impact of science fiction film on student understanding of science. Journal of Science Education and Technology, 15(2) 179-190.

Benzer, E. (2010). Proje tabanlı öğrenme yaklaşımıyla hazırlanan çevre eğitimi dersinin fen bilgisi öğretmen adaylarının çevre okuryazarlı̆̆ına etkisi. [The effect of environment education lesson prepared with project based learning approach on the preservice science teachers' environmental literacy]. Doktora Tezi. Marmara Üniversitesi Eğitim Bilimleri Enstitüsü, İstanbul.

Bilen, K. (2009). Tahmin et-gözle-açıkla yöntemine dayal laboratuvar uygulamalarının öğretmen adaylarının kavramsal başarılarına, bilimsel süreç becerilerine, tutumlarına ve bilimin doğası hakkındaki görüşlerine etkisi [The effects of a laboratory instruction designed based on the predict-observation-explain strategy on preservice teachers' on conceptual achievement, science process skills, attitudes and views about the nature of science]. Doktora Tezi. Gazi Üniversitesi Eğitim Bilimleri Enstitüsü, Ankara.

Birkök, M. C. (2008). Bir toplumsallaştırma aracı olarak eğitimde alternatif medya kullanımı: Sinema filmleri. [Alternate media usage in education as a socialization tool: movies]. Uluslararası Insan Bilimleri Dergisi, 5(2), $1-12$.

Borhan, M. T. \& İsmail, Z. (2011). Promoting environmental stewardship through project based learning. International Journal of Humanities and Social Science, 1(4), 180-186.

Cavanaugh, T. W. \& Cavanaugh, C. (1996, October). Learning science with science fiction films. The annual meeting of Florida Association of Science Teachers, Key West, FL.

Cavanaugh, T.W. \& Cavanaugh, C. (2004). Teach science with science fiction films: a guide for teachers and library media specialist. Worthington, Ohio: Linworth Publishing, Inc.

Chawla, L. \& Cushing, D. F. (2007). Education for strategic environmental behavior. Journal of Environmental Education Research, 13(4), 437-452.

Chew, C. (2008). Effects of biology infused demonstrations on achievement and attitudes in junior college. Unpublished Ph.D Thesis. The University of Western Australian Education of Faculty.

Cebeci, Z. (2003). Öğrenim nesnelerine giriş [Introduction to learning objects]. Elektronik Sosyal Bilimler Dergisi. 6, $1-6$.

Cohen, L., Manion, L. \& Morrison, K. (2007). Research methods in education. London: Routledge Falmer.

Cole, A. G. (2007). Expanding the field: Revisiting environmental education principles through multidisciplinary frameworks. Journal of Environmental Education, 38(2), 35-44.

Cook, T. D. \& Campbell, D. T. (1979). Quasi-experimentation: design and analysis issues for field settings. Chicago: Rand McNally.

Çemrek, F., Anılan, B., Anılan, H., Balbağ, M. Z. \& Görgülü, A. (2005, September). The reflection of the science fiction films on the teachers' success in science classes. Paper presented at the XIV. National Education Science Congress, Pamukkale University Faculty of Education, Denizli.

Çepni, S. (2007). Araştırma ve proje çalışmalarına giriş. [Introduction to research and project studies]. Trabzon: Celepler Matbaacilı. 
Dalhgren, M. A. \& Oberg, G. (2001). Questioning to learn and learning to question: Structure and function of problembased learning scenarios in environmental science education. Higher Education, 41, 263 - 282.

Demircioğlu, İ. H. (2007). Tarih öğretiminde filmlerin yeri ve önemi. [The place and importance of films in history teaching]. Bilig, 42, 77-93.

Demirkuş, N., Bozkurt, T. \& Gülen, S. (2017). Popüler çevre kavramlarının eğitiminde görsel materyal geliştirme çalışması. [The study of development visual material in education on popular environmental concepts]. Ahi Evran Üniversitesi Kırşehir Eğitim Fakültesi Dergisi (KEFAD), 18, 145-157.

Depover, C., Giardina, M. \& Marton, P. (1998). Les environnements d'apprentissage multimédia. Paris, L'Harmattan.

Ekem, N. (1990). The effect of science-fiction movies attitudes towards science and personality development on communication of education. Journal of Fiction, 8, 501-541.

Erten, S. (2006, 7-9 Eylül). Nasıl bir çevre eğitimi? ve çevre dostu davranışlar kazandırmaya yönelik örnek uygulamalar. [What kind of environmental education? And model practices aimed to gained friendly environmentally behaviors]. Paper presented at the VII. Ulusal Fen ve Matematik Eğitimi Kongresi, Gazi Üniversitesi, Ankara.

Farmer, J., Knapp, D. \& Benton, G. M. (2007). An elementary school environmental education field trip: Long-term effects on ecological and environmental knowledge and attitude development. The Journal of Environmental Education, 38(3), 33-42.

George, D. \& Mallery, P. (2003). SPSS for Windows step by step: a simple guide and reference. Boston: Allyn \& Bacon.

Gülay, H. \& Önder, A. (2011). Sürdürülebilir gelişim için okulöncesi dönemde çevre eğitimi [Environmental education in the preschool term for sustainable development] Ankara: Nobel Yayınc1lik.

Güven Yildırım, E. (2015). Science teacher candidates' portraits of science teaching as a profession by using the characters in the movie "3 Idiots”. Educational Sciences: Theory \& Practice, 15(5), 1363-1372.

Güven Yıldırım, Köklükaya, N. \& Selvi, M. (2015). Öğretim materyali olarak 3-Idiot filmi ile öğretmen adaylarının günlük hayatta fenin kullanımı ve eğitimde aile rolü üzerine görüşlerinin belirlenmesi. [Determination of candidate teachers' opinions on science in everyday life and family role in process of education with 3-Idiots movie as a teaching material]. Trakya Üniversitesi Eğitim Fakültesi Dergisi, 5 (2), 94-105.

Güven, E. \& Aydoğdu, M. (2012). Çevre sorunlarına yönelik farkındalık ölçeğinin geliştirilmesi ve öğretmen adaylarının farkındalık düzeylerinin belirlenmesi [Development of an awareness scale and determination of teacher candidates' awareness levels regarding environmental problems]. Öğretmen Eğitimi ve Ĕ̈itimcileri Dergisi, 1(2), 185-202.

Güven, E. (2011). Çevre eğitiminde tahmin gözlem açılklama destekli proje tabanlı öğrenme yönteminin farklı değişkenler üzerine etkisi ve yönteme ilişkin öğrenci görüşleri. [The effect of project based learning method supported by prediction- observation- explanation on different variations in environmental education and students' views concerning this method]. Doktora tezi Gazi Üniversitesi Eğitim Bilimleri Enstitüsü, Ankara.

Güven, E. (2013). Çevre sorunlarına yönelik tutum ölçeğinin geliştirilmesi ve öğretmen adaylarının tutumlarının belirlenmesi [Development of environmental problems attitude scale and determination of teacher candidates' attitudes]. GEFAD, 33(2), 411-430.

Hassan, A., Juahir, H. \& Jamaludin, N. S. (2009). The level of environmental awareness among students to fulfill the aspiration of national philosophy of education. American Journal of Scientific Research, 5, 50-58.

Hassan, A., Noordin, T. A. \& Sulaiman, S. (2010). The status on the level of environmental awareness in the concept of sustainable development amongst secondary school students. Procedia - Social and Behavioral Sciences, 2(2), 1276-1280.

İnce Yakar, H. G. (2013). Sinema filmlerinin eğitim amaçlı kullanımı: tarihsel bir değerlendirme. [Educational use of cinema films: a historical assessment]. Hasan Ali Yücel Eğitim Fakültesi Dergisi, 19(1), 21-36.

Karahan, E. \& Roehrig, G. (2015). Constructing media artifacts in a social constructivist environment to enhance students' environmental awareness and activism. Journal of Science Education and Technology, 24, $103-118$.

Karasar, N. (2004). Bilimsel araştırma yöntemleri [Scientific research methods]. Ankara: Atlas Yayın Dağıtım.

Kaşkaya, A., Ünlü, İ. Akar S. \& Özturan Sağırlı, M. (2011). The effect of school and teacher themed movies on preservice teachers' professional attitudes and perceived self-efficacy. Educational Sciences: Theory \& Practice, 11(4), 1765-1783.

Kaushal, T. \& Singhal, A. (2011). Environmental responsibilities among prospective teachers. International Referred Research Journal, 2(18), 15-16.

Kossack, A. \& Bogner, F. X. (2012). How does a one-day environmental education programme support individual connectedness with nature? Journal of Biological Education, 46(3), 180-187.

Kostova, Z. \& Atasoy, E. (2008). Methods of successful learning in environmental education. Journal of Theory and Practice in Education, 4(1), 49-78.

Köklü, N., Büyüköztürk, Ş. \& Çokluk, Bökeoğlu, Ö. (2006). Sosyal bilimler için istatistik. [Statistics for social sciences]. Ankara: Pegem A Yayıncılık.

Köklükaya, N. (2014). The determination of opinions of pre-service science teachers on the curriculum of science courses on the basis of the 3-Idiots movie. Journal of Baltic Science Education, 14(3), 366-378.

Köseoğlu, F., Tümay, H. \& Kavak, N. (2002, 16-18 Eylül). Yapılandırıcı öğrenme teorisine dayanan etkili bir öğretim yöntemi tahmin et-gözle-açıkla, buz ile su kaynatılabilir mi? [An effective teaching method based on 
constructivist learning theory, predict observe explain. Does water boiled with ice?]. Paper presented at the V. Ulusal Fen Bilimleri ve Matematik Eğitimi Kongresi, Ankara.

Laprise, S. \& Winrich, C. (2010). The impact of science fiction films on student interest in science. Journal of College Science Teaching, 4(2), 45-49.

Larijani, M. (2010). Assessment of environmental awareness among higher primary school teachers. Journal of Hum Ecol, 31(2), 121-124.

McCormick, P. (2007). Film school: Teacher-student relationships in movies can be inspirational or downright creepy. But as catholics it's up to us to help each other learn and grow. Retrieved 14.02.2018, from the http://www.thefreelibrary.com/Film+school $\% 3 \mathrm{a}+$ teacherstudent+relationships + in + movies $+\quad$ can + be...a0162470179.

McGibbon, C. \& Van Belle, J. P. (2015). Integrating environmental sustainability issues into the curriculum through problem-based and project-based learning: a case study at the University of Cape Town. Current Opinion in Environmental Sustainability, 16; 81-88.

Mertler, C. A. \& Charles, C. M. (2011). Introduction to educational research. Boston, MA: Pearson Education Inc.

Michel, E., Roebers, C., M., \& Schneider, W. (2007). Educational films in the classroom: increasing the benefit. Learning and Instruction, 17(2), 172-183.

Mitchell, C. \& Weber, S. (1999). Reinventing ourselves as teachers. Philadelphia: Falmer Press.

Morgan, C. T. (2000). Psikolojiye giriş. (Trans: Hüsnü Arıcı \& Orhan Aydın). Ankara: Hacettepe Üniversitesi Psikoloji Bölümü Yayınları.

North America Association for Environmental Education. (2004). Guidelines for the preparation and professional development of environmental educators. Washington, DC: Author. Retrieved 11.02.2018, from http://eelinked.naaee.net/n/elp.

Oweini, A. \& Houri, A. (2006). Factors affecting environmental knowledge and attitudes among Lebanese college students. Applied Environmental Education and Communication, 5, 95-105.

Özmen, D., Çetinkaya, A. Ç. \& Nehir, S. (2005). Üniversite öğrencilerinin çevre sorunlarına yönelik tutumları [University students' attitudes towards environmental issues]. TSK Koruyucu Hekimlik Bülteni, 4(6), 330-344.

Özyılmaz Akamca, G. \& Hamurcu, H. (2009). Analojiler, kavram karikatürleri ve tahmin-gözlem-açıklama teknikleriyle desteklenmiş fen ve teknoloji eğitimi [Science and technology education based on analogies, concept cartoons and predict-observe-explain techniques]. E-Journal of New World Sciences Academy, 4(4), 1186-1206.

Palmberg, I. E. \& Kuru, J. (2000). Outdoor activities as a basis for environmental responsibility. The Journal of Environmental Education, 31(4), 32-36.

Patton, M. (2002). Qualitative research and evaluation methods. Thousand Oaks, CA: Sage Publications.

Polsani, P., R. (2003). Use and a buse of reusable learning objects, Journal of Digital Information. 3,(4), 76-84.

Russell, D. W., Lusac, K. B. \& Mcrobbie, C. J. (2003). The role of the microcomputer-based laboratory display in supporting the construction of new understandings in kinematics. Research in Science Education, 33(2), 217243.

Russell, D. W., Lusac, K. B. \& Mcrobbie, C. J. (2004). Role of the microcomputer based laboratory display in supporting the construction of new understandings in thermal physics. Journal of Research in Science Teaching, 41(2), 165-185.

Sauvé, L. (2005). Currents in environmental education - mapping a complex and evolving pedagogical field. The Canadian Journal of Environmental Education, 10, 11-37.

Schusler, T. M. \& Krasny, M. E. (2008). Youth participation in local environmental action: developing political and scientific literacy. (Eds: Reid, A., Jensen, B. B., Nikel, J. \& Simovska, V.). Participation and learning: perspectives on education and the environment. Health and sustainability. London: Springer.

Sears, D. O. \& Abeles, R. P. (1969) Attitudes and opinions. Annual Review of Psychology, 20, 253-288.

Selanik Ay, T. (2010). Sosyal bilgiler dersinde çevre bilinci kazandırmada medya ürünlerinden yararlanmaya ilişkin öğrenci görüşleri. [Social studies course student views on environmental awareness gaining media products to exploit]. Uluslararasi Avrasya Sosyal Bilimler Dergisi, 1(1), 76-93.

Shobeiri, S. M., Omidvar, B. \& Prahallada, N. N. (2007). A comparative study of environmental awareness among secondary school students in Iran and India. International Journal of Environmental Reservation, 1(1), 28-34.

Sim, J. \& Wright, C. (2002). Research in health care: concepts, designs and methods. United Kingdom, Cheltenham: Nelson Thornes Ltd.

South, J. B. \& Monson, D. W. (2000) A University-wide system for creating, capturing, and delivering learning objects. Retrived 31.01.2018, from http://www.reusability.org/read/chapters/south.doc.

Stoddard, J. D. (2009). The ideological implications of using educational film to teach controversial events. Curriculum Inquiry, 39(3), 407-433.

Sürmeli, H. (2012). Examination the effect of science fiction films on science education students' attitudes towards STS course. Procedia Social and Behavioral Sciences, 47, 1012-1016.

Tahiroğlu, M., Yıldırım, T. \& Çetin, T. (2010). Değer eğitimi yöntemlerine uygun geliştirilen çevre eğitimi etkinliğinin, ilköğretim 7. sınıf öğrencilerinin çevreye ilişkin tutumlarına etkisi. [The effects of environmental education activities based on value education on $7^{\text {th }}$ grade students' attitudes toward environment]. Ahmet Keleşoğlu Eğitim Fakültesi Dergisi, 30, 231-248. 
Takmaz, S., Yılmaz, M. \& Kalpaklı, F. (2018). Doğa ve çevre eğitimi için öğretim materyali olarak Avatar filmi. [Avatar as an instructional material in environmental training/education]. Pamukkale Üniversitesi Sosyal Bilimler Enstitüsü Dergisi, 30, 249- 263.

Tal, R. T. (2004). Using a field trip to a wetland as a guide for conceptual understanding in environmental education: A case study of a pre-service teacher's research. Chemistry Education: Research \& Practice, 5(2), $127-142$.

Toumey, C., Besley, J., Blanchard, M., Brown, M., Cobb, M., Ecklund, E. H., Glass, T.M. Guterbock, A. E. Kelly, \& Lewenstein, B. (2010). Science in the service of citizens \& consumers: The NSF workshop on public knowledge of science. Retrieved 20.01.2018, from http://nano.sc.edu/resources/publications.aspx

UNESCO-UNEP. (1976). The Belgrade Charter: A global framework for environmental education. Connect: UNESCO-UNEP Environmental Education Newsletter, 1(1), 1-2.

UNESCO-UNEP. (1978). Final report, intergovernmental conference on environmental education, Tbilisi (USSR), October 14-26, 1977. Paris: UNESCO-UNEP.

Vaughan, C., Gack, J., Solorazano, H. \& Ray, R. (2003). The effect on environmental education on school children, their parents, and community members: a study of intergenerational and intercommunity learning. The Journal of Environmental Education, 34(3), 12-21.

Whiteman, D. (2009). Documentary film as policy analysis: The impact of yes, in my backyard on activists, agendas, and policy. Mass Communication and Society, 12(4), 457-477.

Vishwanath, H. N. (2006). Models of teaching in environmental education. New Delhi, India: Discovery.

Watts, R. (2007). Harnessing the power of film in the primary classroom. Literacy, 41(2), 102- 109.

Wenger, R. (1943). Motion pictures in teacher education. Educational Research Bulletin, 22(4), 90-96.

Wiley, D.A.(2002). Connecting learning objects to instructional design theory: A definition, a metaphor, and a taxonomy. Retrived 11.03.2018, from http://www.reusability.org/read/chapters/wiley.doc.

Zualkernan, I. A., Jibreel, M., Tayem, R. \& Zakaria, R. (2009, 15-17 July). A roleplaying game-based learning platform for environmental awareness. Paper presented at the Advanced Learning Technologies, $9^{\text {th }}$ IEEE International Conference, Latvia. 